\title{
OLIVACEOUS CORMORANT - FIRST RECORD FOR CANADA
}

FRANK BRAZIER, 2657 Cameron Street, Regina, Saskatchewan. S4T 2W5

The morning of 8 September 1989 in Regina was a dull one, overcast, with occasional brief light rain showers. About 10:00 a.m. I was walking eastward on the north side of Wascana Lake and when I was opposite the north end of Willow Island I left the asphalt walkway and crossed an open area towards a gap in the dense carragana hedge which grows along the bank. The instant I reached the gap a cormorant skittered along the water in panic and flew westward out of sight. It was about $15 \mathrm{~m}$ from me when it took off. I thought, "What a small cormorant! And why the panic?" The Double-crested Cormorants which frequent Wascana Lake in spring and fall often allow a fairly close approach, and then usually dive rather than fly.

Later, at about 11:30 a.m., I had reached the south end of Albert Memorial Bridge at the west end of Wascana Lake and was walking north over it when the thought struck me that the small cormorant may have joined the few Doublecresteds that are often on the deep water on the east side of the bridge (which contains a weir), so I stopped at a bench and scanned the water. Sure enough! With four Double-cresteds I could see the small one swimming placidly, and through my binoculars I could see that its neck was noticeably thinner and shorter than that of the others; the gular pouch was a dull yellow, with some white on either side. The front of the neck and that part of the breast visible was also yellowish, indistinguishable from the pouch colour at that distance (ca. $25 \mathrm{~m}$ ). The most noticeable feature was its small size compared with the Double-cresteds.
My car was parked nearby and sho I was describing the bird to Paul Jam Saskatchewan Museum of Natural 1 tory staff. Since it was nearly noon decided to go and look, as the locale 1 nearby. I told him to look for a sn cormorant, about half the size of others.

After I got home about 12:30 p.n called Robert Kreba at his home when I had described the bird to him offered an identification as an Olivace Cormorant, because that small cormor had been seen in South Dakota. Reg tably, neither Paul James nor Rol Kreba were able to find the bird I $\}$ seen, nor did anyone else.

Once Bob had given me the clu searched the bird books I had for a $p$ tive identification. Robbins pictured immature Olivaceous with the light str on the foreneck and white on the face reaches the Louisiana Coast where breeds. Lowery states: "The body of 1 species is about half as large in bulk that of the Double-crested Cormoran so my remarks to Paul James were corr as to size. Lowery also notes: "Immatu of the two species in the first wir plumage are indistinguishable from e: other in the field except by size."

The normal range of the Olivace Cormorant extends from the Louisi: coast south to Tiera del Fuego on coa waters and fresh lakes and streams. own records are of observations Mazatlan, Mexico (1975), Trinic (1976), Belize (1978) and Panama (19 but I do not recall seeing immatu which the Wascana bird obviously w: 
ffrench notes that the Olivaceous Corrant is a game bird in Trinidad and bago. ${ }^{4}$ My experience in Mexico leads to suggest that these birds are also ken for the pot, along with anything else it's edible. This would explain the nic flight I saw.

This cormorant in the literature has n known as Neotropic, Brazilian, xican, and Bigua, but Olivaceous is name now used.

he Olivaceous Cormorant often apirs on the California coast, and there some inland records. Possibly those occur in the Gulf of California ider north as there are records in theastern Arizona at Lake Patagonia; ${ }^{2}$ I Paso, Texas (31 Jan., 10 Feb. 1983), Nebraska (Oct. 1982); $i^{10}$ at Lake d, Nevada (16 Dec. 1978, 12 March 9); ${ }^{5}{ }^{6}$ Lamar, Colorado (17 July ust 1988); Pierre South Dakota (3 July August 1985 - first state record); ${ }^{3}$ re, S. Dakota, (23 June 1987 - second record).

lave searched the "Indexes of boldd birds" of American Birds and its lecessor Audubon Field Notes back 21 (1967), as well as every issue of finding in Canada, and the indexes of adian Field-naturalist and its ecessors back to 1924, without findany mention of Olivaceous tropic) Cormorant. The books Birds anada, revised edition, and The ralist's guide to the Victoria region do ecord it, nor does the Checklist of of Victoria and Southeastern Vaner Island (May 1989). If any bird lered north along the Pacific coast to da the latter two publications ably would have recorded such a entous event. In addition I wrote to Nero in Winnipeg, but he knew of htings for Manitoba, and also Alan nington, of Point Pelee National who stated "There is definitely no record of Olivaceous Cormorant in Canada ..." I believe my sighting of one on 8 September 1989 on Wascana Lake in Regina is the first for Canada.

I thank Robert Nero and Alan Wormington for their assistance.

I offer the above sighting of an Olivaceous Cormorant as an addition to the hypothetical list of Saskatchewan birds.

BERKEY, G.B. 1987. The nesting season, June 1 - July 31, 1987. Am. Birds 41(3):

2 DAVIS, W.A. and S.M. RUSSELL. 1979. Birds in southeastern Arizona. Tucson Audubon Soc., Tucson.

${ }^{3}$ FAANES, C.A. 1985. The nesting season, June 1 - July 31, 1985. Am. Birds 39(5):

${ }^{4}$ FFRENCH, RICHARD. 1973. A guide to the birds of Trinidad and Tobago. Livingston Publ. Co., Wynnewood, Pa.

${ }^{5}$ KINGERY, H.E. 1979. The winter season, Dec. 1, 1978 - Feb 28, 1979. Am. Birds 33(3):

${ }^{6}$ KINGERY, H.E. 1979. The spring migration, Mar. 1 - May 31, 1979. Am. Birds 33(5):

KINGERY, H.E. 1985. The nesting season, June 1 - July 31, 1985. Am. Birds 42(5):

${ }^{8}$ LOWERY, G.H., Jr. 1960. Louisiana birds. Louisiana State Univ. Press, Baton Rouge

${ }^{9}$ ROBBINS, C.S. 1966. Birds of North America. Golden Press, N.Y

10 WILLIAMS, FRANCES. 1983. The winter season, Dec. 1, 1982 - Feb. 28, 1983. Am. Birds 37(3): 